\title{
Effect of Chemical Composition on the Microstructure of Carbide Reinforced Indefinite Chilled Rolls
}

\author{
Genzhe HUANG, Zenghui LI, Jianyin TANG and Ye TIAN
}

School of Electromechanical Engineering, Changchun University of Science and Technology, Changchun, 130022 P.R. China.

(Received on December 7, 2010; accepted on March 18, 2011)

\begin{abstract}
In the present work, effects of elements such as $\mathrm{V}, \mathrm{Nb}, \mathrm{Si}$ and $\mathrm{Cr}$ on the microstructures of the conventional indefinite chilled rolls made by small vertical centrifugal caster were investigated, using optical microscopy, Scanning Electron Microscopy (SEM, Jeol 6400), Energy Dispersive X-ray Spectroscopy (EDXS, Cu-K $\alpha$ radiation) to identify the type, morphology, and to measure the volume fraction and the distribution of carbides and graphites formed during solidification. Microstructural analysis indicates that, the amount of graphite is dramatically reduced by adding $V$ element. The volume fraction of the square-like carbides $\mathrm{NbC}$ increases with the $\mathrm{Nb}$ content increasing. However, if $\mathrm{Nb}$ content is over a critical point, large amount of the square-like $\mathrm{NbC}$ carbide can be seriously segregated in the out part of the section. The test also shows that, by increasing $\mathrm{Si}$ and reducing $\mathrm{Cr}$ content, the volume fraction of the graphite increases accordingly, whereas much of its shape turns to be finely flake-like. In addition, it can be found from the microstructures observed by optical microscopy that, the volume percentage of the rod-like $\mathrm{NbC}$ carbides increases as the examining position is near the inner portion of the section, and that of the cubic-like $\mathrm{NbC}$ carbides decreases contrarily.
\end{abstract}

KEY WORDS: indefinite chilled roll; carbide; graphite; wear-resistance.

\section{Introduction}

In recent years, as high chromium iron rolls have been substituted gradually with high speed steel rolls in front stands of hot strip mills, strip surface quality, rolling productivity and roll changing efficiency are significantly improved. Whereas further increasing mill campaign capacity and reducing cost are limited unfortunately due to the poor wear-resistance of conventional indefinite chilled (IC) rolls in rear stands. So it would be urgently necessary to develop a new type of highly wear-resistant indefinite chilled rolls in order to increase the mill campaign.

However, if the more rolls are located near the rear stands, the more the surface quality of the hot strip products is affected by their surface morphology. As a result, the wear-resistance and anti-roughness abilities at the roll surface have to be further improved in finishing stand work rolls, because their performance can directly influence the quality of the hot strip products. Furthermore comparing with the front stands, although the rolling reduction on rear stands is relatively lower, the rolling speed is higher. Therefore, fire crack-resistance and anti-accident abilities of the work rolls are also important to confront heat impact resulted from the rolling accident such as fold over strip (crimp, pinch, chew-up), when rolling thin hot strip products with high speed.

It is well known that, commercial IC rolls normally consist of $30-40 \%$ cementite $\left(\mathrm{Fe}_{3} \mathrm{C}\right), 3-5 \%$ well-distributed flake-like graphite and bainitic matrix, mixed with a little of martensite. The graphite in IC rolls can significantly increase the lubrication between work roll and strip, enhance the heat conduction within roll section, and lower or inhibit fire crack initiation and propagation because of low modulus of elasticity of the graphite. ${ }^{1)}$ Otherwise, the matrix and cementite are mainly in charge of enhancing roll surface wear-resistance and making rolled coils have more homogeneous thickness. Nevertheless, their effect on wearresistance and anti-roughness are usually limited because of relatively low hardness of the cementite (HV1040), ${ }^{2)}$ though the volume percentage of the cementite is basically high.

It is well demonstrated in this report that, the wear-resistance of indefinite chilled IC rolls can be significantly increased by forming highly hardened $\mathrm{NbC}$ or $\mathrm{VC}$ carbides in casting process (HV2400-2800), ${ }^{3)}$ when added strong carbide former such as $\mathrm{Nb}$ and $\mathrm{V}$. This newly developed indefinite chilled roll was named Carbide Reinforced Indefinite Chilled (CRIC) roll. We also intend to present essential conditions of the alloy design by investigating the effect of these elements on the microstructure. Six sleeve rolls were fabricated by suitably varying the contents of $\mathrm{V}, \mathrm{Nb}, \mathrm{Si}$ and $\mathrm{Cr}$, and their respective effect on microstructure and hardness values were carefully investigated.

\section{Experimental}

The materials used in this test were six CRIC rolls, manufactured by vertical centrifugal casting method without pouring core materials (sleeve rolls), where the chemical compositions are listed in Table 1. Mold inner diameter and length are $400 \mathrm{~mm}$ and $900 \mathrm{~mm}$, thickness of the casting 
sleeves and investigated position along the axial direction are about $50 \mathrm{~mm}$ and $450 \mathrm{~mm}$ respectively. Rotating speed of the mold during centrifugal casting is 735RPM (equals to centrifugal force $120 \mathrm{G}$ in the inner diameter of the mold). The basic composition of the CRIC roll is $3.4 \mathrm{C}-0.9 \mathrm{Si}-$ $0.7 \mathrm{Mn}-4.4 \mathrm{Ni}-1.8 \mathrm{Cr}-0.4 \mathrm{Mo}$ (wt. $\%$ ), and the rolls are chemically designed to be able to investigate the effects of $\mathrm{V}, \mathrm{Nb}$, $\mathrm{Si}$ and $\mathrm{Cr}$ on the microstructure. Roll-A is a traditional IC roll. Roll-B is the one that is only added $0.55 \% \mathrm{~V}$ based on the roll-A in order to investigate the $\mathrm{V}$ effect. Roll- $\mathrm{C}_{1},-\mathrm{C}_{2}$ and $-\mathrm{C}_{3}$ contain $0.5 \%, 1.0 \%$ and $2.0 \%$ of $\mathrm{Nb}$ respectively, based on the roll-B for the observation of the $\mathrm{Nb}$ behaviors. Roll-D is made by changing Si from $0.9 \%$ to $1.3 \%$ and $\mathrm{Cr}$ from $1.8 \%$ to $1.6 \%$ respectively, based on the roll- $\mathrm{C}_{2}$.

The samples were polished and etched in $4 \%$ nital, and were observed by an optical microscopy and a Scanning Electron Microscopy (SEM). Special niobium carbides $\mathrm{NbC}$ were identified by using Murakami etchant $\left.{ }^{4}\right)\left(3 \mathrm{~g} \mathrm{~K}_{3} \mathrm{Fe}\right.$ $\left.(\mathrm{CN})_{6}+10 \mathrm{~g} \mathrm{NaOH}+100 \mathrm{ml} \mathrm{H}_{2} \mathrm{O}\right)$ after clearly polished. As a result, the $\mathrm{NbC}$ carbides were selectively etched (black) but not the matrix and $\mathrm{Fe}_{3} \mathrm{C}$. The cell size, volume fraction of the various carbides, and the graphites were quantitatively analyzed by using an image analyzer. Specifically, the cell size here means the measurement of blocks solidified from

Table 1. Chemical composition of the investigated CRIC rolls (wt.\%).

\begin{tabular}{cccccccccccc}
\hline Rolls & $\mathrm{C}$ & $\mathrm{Si}$ & $\mathrm{Mn}$ & $\mathrm{P}$ & $\mathrm{S}$ & $\mathrm{Ni}$ & $\mathrm{Cr}$ & $\mathrm{Mo}$ & $\mathrm{V}$ & $\mathrm{Nb}$ & Remarks \\
\hline $\mathrm{A}$ & 3.40 & 0.90 & 0.70 & $\leq 0.10$ & $\leq 0.02$ & 4.40 & 1.80 & 0.40 & None & None & Normal \\
\hline $\mathrm{B}$ & 3.40 & 0.90 & 0.70 & $\leq 0.10$ & $\leq 0.02$ & 4.40 & 1.80 & 0.40 & 0.55 & None & V-Effect \\
\hline $\mathrm{C}_{1}$ & 3.40 & 0.90 & 0.70 & $\leq 0.10$ & $\leq 0.02$ & 4.40 & 1.80 & 0.40 & 0.55 & 0.50 & \\
$\mathrm{C}_{2}$ & 3.40 & 0.90 & 0.70 & $\leq 0.10$ & $\leq 0.02$ & 4.40 & 1.80 & 0.40 & 0.55 & 1.00 & Nb-Effect \\
$\mathrm{C}_{3}$ & 3.40 & 0.90 & 0.70 & $\leq 0.10$ & $\leq 0.02$ & 4.40 & 1.80 & 0.40 & 0.55 & 2.00 & \\
\cline { 1 - 5 } $\mathrm{D}$ & 3.40 & 1.30 & 0.70 & $\leq 0.10$ & $\leq 0.02$ & 4.40 & 1.60 & 0.40 & 0.55 & 1.00 & \multirow{2}{*}{$\mathrm{Si}$, Cr-Effect }
\end{tabular}

primary gamma or MC carbide, then continuously crystallized by eutectic reaction $\mathrm{L} \rightarrow$ gamma+MC. Additionally, the sample was also deeply etched in order to remove matrix, using an etchant of $5 \mathrm{~g} \mathrm{FeCl}_{3}+10 \mathrm{ml} \mathrm{HNO}_{3}+3 \mathrm{ml} \mathrm{HCl}+87$ $\mathrm{ml}$ ethyl alcohol ${ }^{5)}$ to observe the three-dimensional shape of $\mathrm{NbC}$ carbides in an SEM. An X-ray diffractometry was used to confirm the type of carbides. Overall bulk hardness values were carefully measured by Vickers hardness tester at a load of $30 \mathrm{~kg}$, and the data shown here was the average of five points.

\section{Results}

Figure 1(a) through (f) are the optical micrographs of the six CRIC rolls etched by Murakami etchant after clearly polishing. In the roll-A that does not contain $\mathrm{V}$ and $\mathrm{Nb}$ strong carbide forming elements, flake-like graphites similar to that of the commercial IC rolls were observed (Fig. 1(a)). However, in the roll-B, after added $0.55 \% \mathrm{~V}$ based on the roll-A, the flake-like graphites were changed to become sphere-like and well uniformly distributed in the region (Fig. 1(b)), and there were not any vanadium carbides VC crystallized (SEM image at the left lower corner in Fig. 1(b), $4 \%$ nital etching). In the roll- $\mathrm{C}_{1},-\mathrm{C}_{2}$ and $-\mathrm{C}_{3}$, contained $0.5 \%, 1.0 \%$ and $2.0 \%$ of $\mathrm{Nb}$ contents respectively on the base of the roll-B, the shape of the formed graphites is mostly sphere-like. In addition, small black particles were uniformly distributed, and the number of these particles increases in order of the roll- $\mathrm{C}_{1},-\mathrm{C}_{2}$ and $-\mathrm{C}_{3}$ accordingly (Figs. 1(c), 1(d), 1(e)). Moreover, the small black particle size of the roll- $\mathrm{C}_{3}$ is a little larger than that of the roll- $\mathrm{C}_{1},-\mathrm{C}_{2}$. In the roll-D, without changing $\mathrm{V}$ and $\mathrm{Nb}$ contents and only varying $\mathrm{Si}$ from $0.9 \%$ to $1.3 \%, \mathrm{Cr}$ from $1.8 \%$ to $1.6 \%$ respectively based on the roll- $\mathrm{C}_{2}$, the number of the small black particles was nearly the same as that of the roll- $\mathrm{C}_{2}$, but the morphology of the graphite was turned to be the flake-like
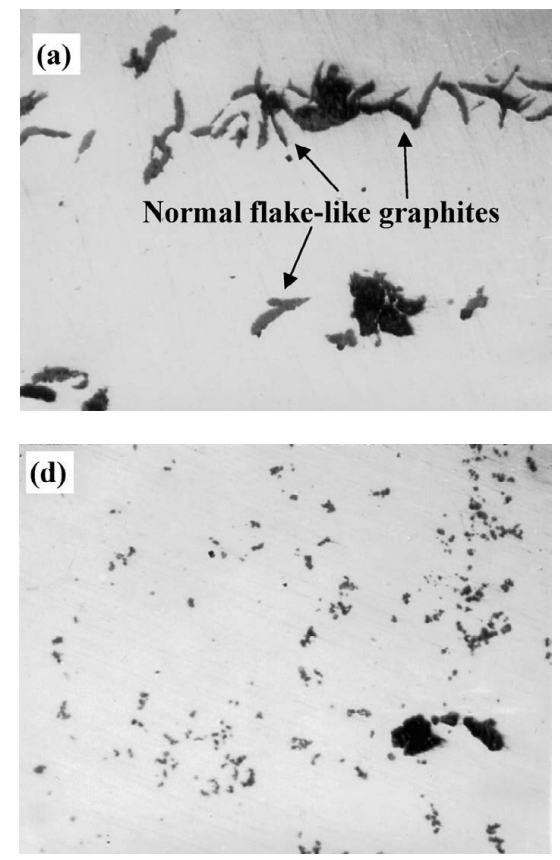
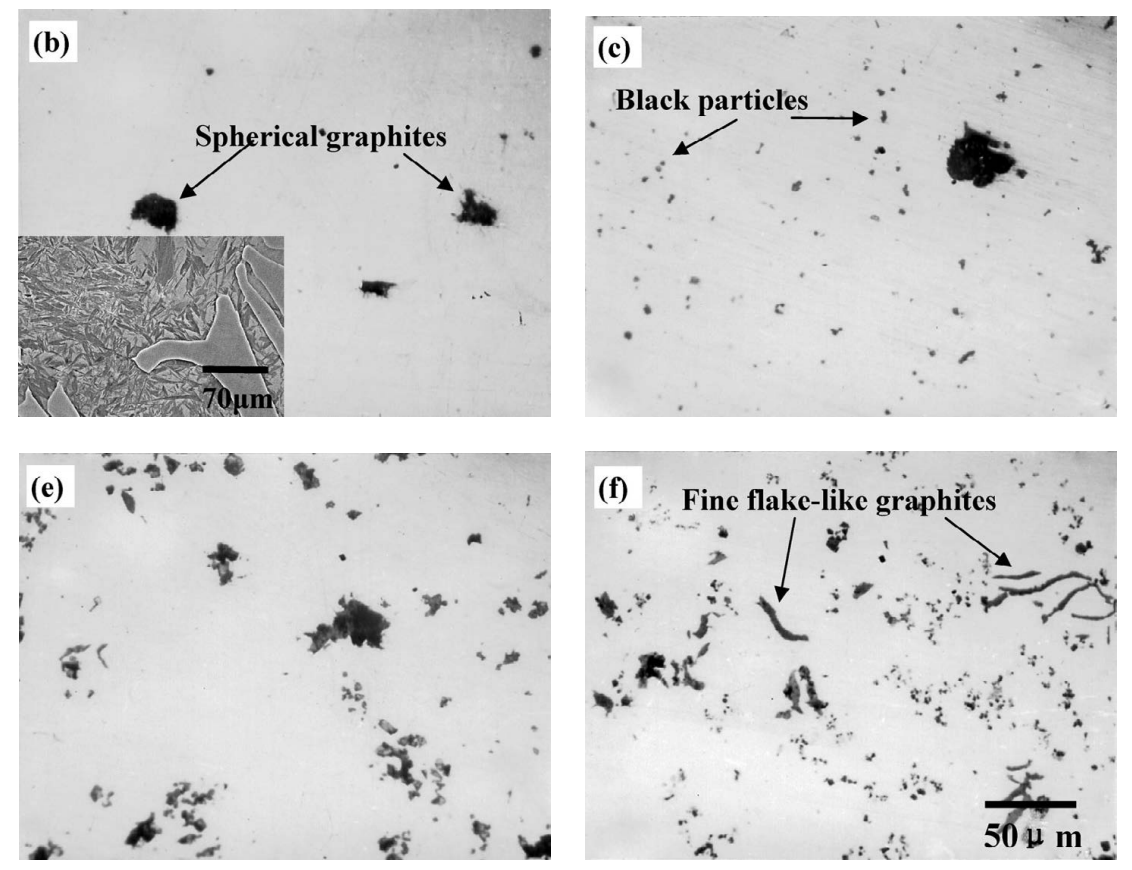

Fig. 1. (a)-(f) Optical micrographs of six CRIC rolls after Murakami etching with SEM image at the left lower corner in Fig.1.(b) after $4 \%$ nital etching, showing that there are not any vanadium carbides VC crystallized. 
instead of being sphere-like (Fig. 1(f)). When overlooked the whole sleeve section of $50 \mathrm{~mm}$ region in detail, the small black particles for the roll- $\mathrm{C}_{1},-\mathrm{C}_{2}$ were homogeneously distributed over the whole section, whereas in the roll- $\mathrm{C}_{3}$, the similar particles were densely segregated at about $10 \mathrm{~mm}$ width at the outer region of the section (Fig. 2). In order to identify this kind of the black particles appeared in the roll$\mathrm{C}_{1},-\mathrm{C}_{2},-\mathrm{C}_{3}$ and $-\mathrm{D}$, SEM secondary electron image analysis (Fig. 3(a)), back scattered image analysis (Fig. 3(b)) and EDS inspection (Fig. 3(c)) were carried out in the roll- $\mathrm{C}_{3}$. It can be concluded that, the white particles shown in Fig. 3(b) were $\mathrm{Nb}$-rich carbides, containing mostly $\mathrm{Nb}$ with a small amount of $\mathrm{V}, \mathrm{Ti}$ and $\mathrm{Fe}$, which was correspondent with the small black particles in Figs. 1(c)-1(f). In addition, it was shown in Fig. 3(d) that, the three-dimensional shape of the $\mathrm{Nb}$-rich carbides, after the matrix was removed by deepetching method, seems to be mostly cubic. An X-ray diffraction analysis was conducted on the surface of the deep- etched roll- $\mathrm{C}_{3}$, the results of which were shown in Fig. 4. The X-ray diffraction pattern is identified to be consisted of the peaks of $\mathrm{NbC}\left(\mathrm{Nb}_{4} \mathrm{C}_{3}\right.$ in chemical stoichiometry), $\mathrm{Fe}_{3} \mathrm{C}$ and the remained matrix. Figure 5 indicates the rod-like

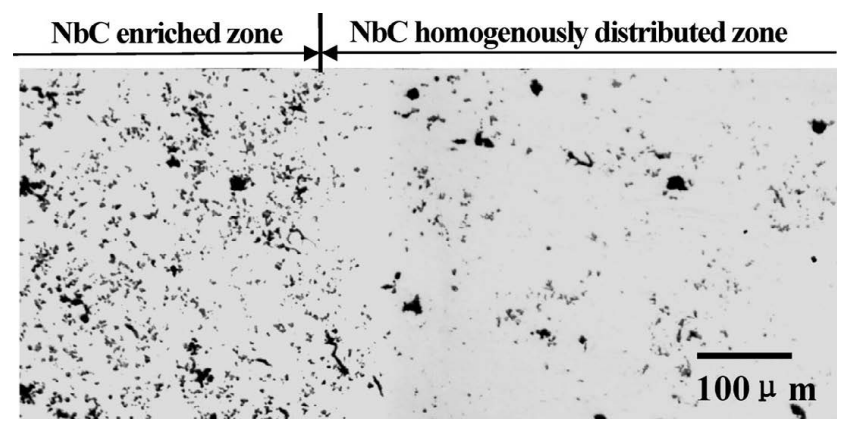

Fig. 2. Density-induced $\mathrm{NbC}$ segregated zone at the outer region of the roll- $\mathrm{C}_{3}$.
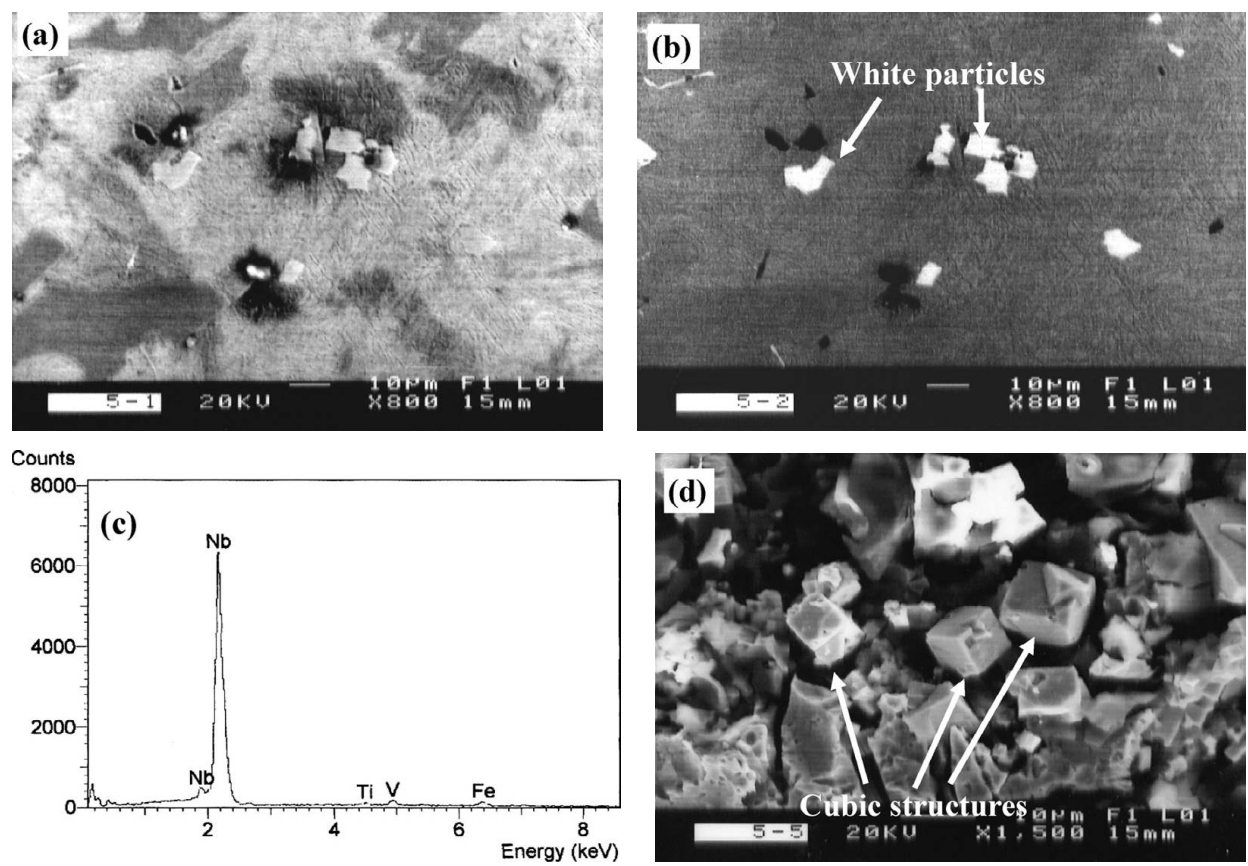

Fig. 3. (a) Secondary electron SEM image, (b) backscattered electron SEM image, (c) EDS spectra of the white particles at the (b), (d) SEM micrograph of the three-dimensional morphology of the NbC carbides, showing cubic structure in the roll- $\mathrm{C}_{3}$.

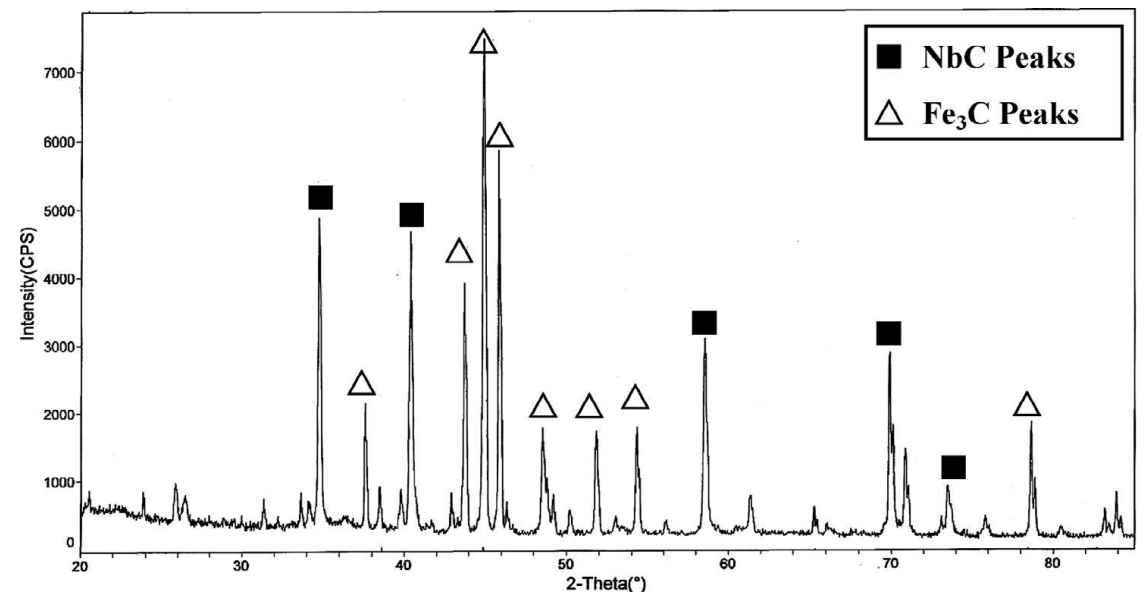

Fig. 4. X-ray diffraction pattern of the roll- $\mathrm{C}_{3}$ after deeply etched, showing peaks of $\mathrm{NbC}$ and $\mathrm{Fe}_{3} \mathrm{C}$. 
shape of $\mathrm{NbC}$ carbides formed at the inner region of the section in the roll- $\mathrm{C}_{3}$. Table 2 quantitatively lists the analytical results on the cell size, the volume fraction of the carbides and the graphites, as well as overall bulk hardness values. The cell size in the roll-A is $56 \mu \mathrm{m}$, which is the largest. The others were relatively ranged between $43-46 \mu \mathrm{m}$. The matrix microstructure of the overall rolls is martensitic because the sleeve samples were subjected to higher cooling rate than commercial roll was, resulted from having no core materials. The volume fraction of $\mathrm{Fe}_{3} \mathrm{C}$ in the roll- $\mathrm{B},-\mathrm{C}_{1}$, $\mathrm{C}_{2}$ and $-\mathrm{C}_{3}$ is at a range of about $37-39 \%$, larger than that of the roll-A and -D. In contrast, the volume percent of the graphites in the roll-B, $-\mathrm{C}_{1},-\mathrm{C}_{2}$ and $-\mathrm{C}_{3}$ was narrowly ranged between $1.2-1.5 \%$, less than that of the roll-A and $-\mathrm{D}$. The volume fraction of the $\mathrm{NbC}$ carbides in the roll- $\mathrm{C}_{1},-\mathrm{C}_{2},-\mathrm{C}_{3}$ and $-\mathrm{D}$ is $1.2 \%, 2.2 \%, 3.7 \%$ and $2.1 \%$ respectively. As a result, the total carbide volume fraction of the roll-B, $-\mathrm{C}_{1}$, $\mathrm{C}_{2},-\mathrm{C}_{3}$ and $-\mathrm{D}$ is about $37-42 \%$, larger than that of the roll-
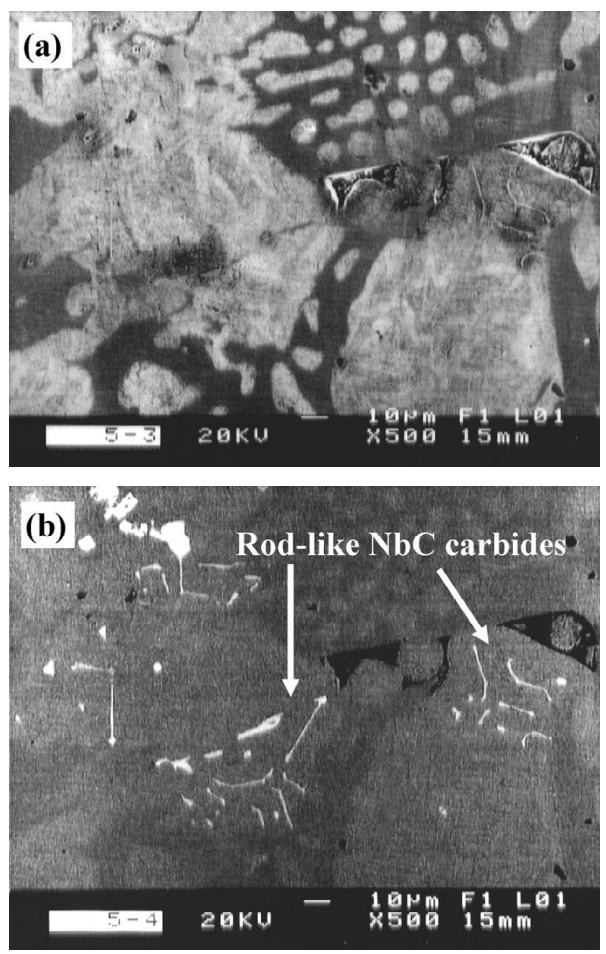

Fig. 5. (a) Secondary electron SEM image, (b) backscattered electron SEM image in the roll- $\mathrm{C}_{3}$, showing rod-like structure of $\mathrm{NbC}$ carbides at the inner region of the section.

Table 2. Results of the quantitative analysis of the CRIC rolls.*

\begin{tabular}{ccccccccc}
\hline & & & \multicolumn{3}{c}{ Carbide volume faction (\%) } & \multicolumn{2}{c}{ Graphites } & Overall \\
\cline { 5 - 8 } Rolls & $\begin{array}{c}\text { Cell } \\
\text { size } \\
(\mu \mathrm{m})\end{array}$ & $\begin{array}{c}\text { Matrix } \\
\text { characteristic }\end{array}$ & $\mathrm{Fe}_{3} \mathrm{C}$ & $\mathrm{NbC}$ & Total & Shape & $\begin{array}{c}\text { Volume } \\
\text { fraction } \\
(\%)\end{array}$ & $\begin{array}{c}\text { Hardness } \\
(\text { VHN)** }\end{array}$ \\
\hline $\mathrm{A}$ & 56 & Martensitic & 33 & - & 33.0 & Normal flake & 4.3 & 741 \\
$\mathrm{~B}$ & 43 & Martensitic & 37 & - & 37.0 & Fine sphere & 1.5 & 762 \\
$\mathrm{C}_{1}$ & 46 & Martensitic & 39 & 1.2 & 40.2 & Fine sphere & 1.3 & 794 \\
$\mathrm{C}_{2}$ & 44 & Martensitic & 37 & 2.2 & 39.2 & Fine sphere & 1.4 & 781 \\
$\mathrm{C}_{3}$ & 43 & Martensitic & 38 & 3.7 & 41.7 & Fine sphere & 1.2 & 795 \\
$\mathrm{D}$ & 44 & Martensitic & 35 & 2.1 & 37.1 & Fine Flake & 2.7 & 763 \\
\hline
\end{tabular}

* All samples were taken at the distance of $15 \mathrm{~mm}$ from as-cast surface.

** Hardness values measured under a load of $30 \mathrm{~kg}$.
A (33\%). The shape of the graphites in the roll-B, $-\mathrm{C}_{1},-\mathrm{C}_{2}$ and $-\mathrm{C}_{3}$ was fine sphere-like, compared with the normal flake-like in the roll-A, and fine flake-like in the roll-D. The overall bulk hardness values of the roll- $\mathrm{C}_{1},-\mathrm{C}_{2}$ and $\mathrm{C}_{3}$ are higher than that of the roll-A, -B and D. Among them, the hardness of the roll-A was the lowest.

\section{Discussions}

As described in the introduction above, hot rolling properties are greatly influenced by various microstructural factors such as: (1) kind, shape, volume fraction, and distribution of carbides and graphite; (2) characteristics of matrix; and (3) solidified cell structure. Carbides can basically enhance wear-resistance of rolls and surface quality of rolled coils since they are relatively hard in comparison with the hardness of the matrix. On the other hand, the amount and the shape of the graphite strongly influence fire crack initiation, anti-accident ability and rolling force etc. ${ }^{6,7)}$ The sphere-like shape and the reasonable amount of the graphite are beneficial to the delay of the fire crack initiation, and can reduce mill accident and rolling force. The matrix is related with overall hardness, strength, and fracture toughness of the used rolls. In addition, matrix can play an important role in binding the carbides, that is to say, if its hardness is higher, it can hold carbide particles effectively, and prevent the carbides fall-off from rolling process, leading to the homogeneous abrasion and better surface roughness of rolls. ${ }^{8)}$ The cell size also plays a critical role in determining the overall carbide distribution, i.e. big cell size relates with carbide continuously surrounding the cell, forming carbide network; whereas small cell size can be contributed to separate the carbides by the relatively soft matrix under constant volume fraction of carbides. Therefore, if cell size is small, heat crack at the roll surface can hardly initiate and propagate along cell boundary because of the dragging behavior by the relatively soft matrix. ${ }^{9)}$ In other words, energy for cracks to be spent in ductile matrix can be larger than that in brittle carbides accordingly. In summary, these microstructural factors should be systematically controlled to optimize the all related mechanical properties, when manufacturing CRIC rolls with excellent rolling performances.

In order to analyze the effects of $\mathrm{Nb}$ added in the CRIC rolls, the liquidus surface diagram showing the solidification process, as illustrated in Fig. 6, is useful. ${ }^{3)}$ Although this diagram is concerned with the system of $\mathrm{Fe}-5 \mathrm{Cr}-\mathrm{Nb}-\mathrm{C}$, it can be applied roughly to the compositional analysis of the

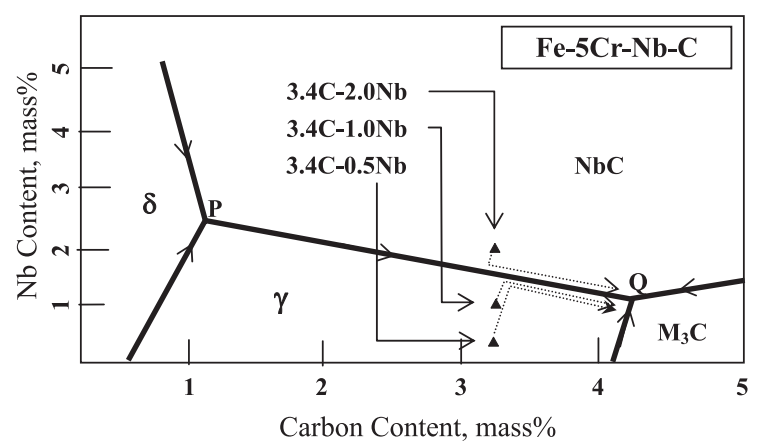

Fig. 6. Liquidus surface of $\mathrm{Fe}-5 \mathrm{Cr}-\mathrm{Nb}-\mathrm{C}$ alloy system. ${ }^{3)}$ 
rolls used here.

According to the solidification theory, solidification proceeds along liquidus surface downward to lower temperature. In the case of the roll- $\mathrm{C}_{1}$ and $-\mathrm{C}_{2}$, the solidification of their liquid phase starts from the points shown as "3.4C$0.5 \mathrm{Nb}$ " and " $3.4 \mathrm{C}-1.0 \mathrm{Nb}$ " in Fig. 6 respectively, moves forward to PQ line, and form primary austenite $(\gamma)$. Upon arriving at PQ line, the solidification lines move toward point $\mathrm{Q}$ along $\mathrm{PQ}$ line, and form $\mathrm{NbC}$ carbides by a eutectic reaction of $\mathrm{L} \rightarrow \boldsymbol{\gamma}+\mathrm{NbC}$. In general, because the eutectic structure $(\gamma+\mathrm{NbC})$ independently nucleates and grows within cell or at the periphery of cementite (Figs. 3(a), 3(b)), it can reduce the locally uneven hardness across the cell structure. Whereas in the case of the roll- $\mathrm{C}_{3}$, the solidification of the liquid phase starts from the point indicated as " $3.4 \mathrm{C}-$ $2.0 \mathrm{Nb}$ " in Fig. 6, and moves forward to PQ line, simultaneously produces primary $\mathrm{NbC}$ carbides. After arriving at PQ line, the solidification line moves further toward point $\mathrm{Q}$ along $\mathrm{PQ}$ line like the roll- $\mathrm{C}_{1}$ and $-\mathrm{C}_{2}$, and forms aggregates of austenite plus $\mathrm{NbC}$ carbide by the eutectic reaction of $\mathrm{L} \rightarrow \gamma+\mathrm{NbC}$. The longer the line is from starting point to the point $\mathrm{Q}$, the longer the time takes for primary $\gamma$ or $\mathrm{NbC}$ and $(\gamma+\mathrm{NbC})$ eutectic structure to grow, and the larger the cells grow. The cell size of roll-A is larger than that of the rest of the rolls (Table 2). It can be reasonably explained that, the line in the roll-A, from starting point to the point $\mathrm{Q}$, may be longer compared with the other rolls, so that there could be a sufficient time to let cell structure grows as a larger one.

As listed in Table 3, the density of the $\mathrm{NbC}$ carbide is $7760 \mathrm{~kg} / \mathrm{m}^{3}$, and it is relatively larger than that of the liquid $\left(7300 \mathrm{~kg} / \mathrm{m}^{3}\right){ }^{3)}$ If $\mathrm{NbC}$ carbide first solidifies independently in the liquid phase under the condition of a high centrifugal force, it will certainly migrates toward the outer portion in the mold, forming density-induced segregation, as can be seen in Fig. 2. In another word, it is difficult to expect that, there will be a high percentage of the $\mathrm{NbC}$ carbides crystallizing in the usable region of the roll depth. As a result, when we are about to design compositions for CRIC rolls, $\mathrm{Nb}$ content can not be allowed to stride over PQ line in order to avoid primary $\mathrm{NbC}$ carbide segregation at the outer region of the rolls.

The report ${ }^{10)}$ revealed that, some of $\mathrm{V}$ can be dissolved in the matrix, so it strongly affects the formation of graphite due to its relatively high affinity with carbon. As indicated in Fig. 7, even if the carbon content is 3.0-3.5\%, the dissolving partition coefficient for $\mathrm{V}$ is about 0.3 . Although this conclusion results from the high speed steel rolls, it can be roughly used to interpret the microstructural behavior of the CRIC rolls. That is to say, as $0.55 \% \mathrm{~V}$ is added in the roll- $\mathrm{B},-\mathrm{C}_{1},-\mathrm{C}_{2}$ and $-\mathrm{C}_{3}$, the volume percentage of their

Table 3. Species, system of symmetry, density, and the hardness of carbides. $^{3)}$

\begin{tabular}{ccccc}
\hline Elements & Carbides & System & $\begin{array}{c}\text { Density }\left(\mathrm{kg} / \mathrm{m}^{3}\right) \\
\text { measured } \\
\text { (theoretical) }\end{array}$ & $\begin{array}{c}\text { Vickers } \\
\text { Hardness } \\
\text { values }\end{array}$ \\
\hline $\mathrm{V}$ & $\mathrm{V}_{4} \mathrm{C}_{3}$ & $\mathrm{NaCl}$ & $5360(5810)$ & 2800 \\
$\mathrm{Nb}$ & $\mathrm{V}, \mathrm{Fe})_{4} \mathrm{C}_{3}$ & & 5800 & 2730 \\
$\mathrm{NbC}$ & $\mathrm{NaCl}$ & $7760(8200)$ & 2400 \\
\hline
\end{tabular}

graphite is sharply reduced to a narrow range of $1.2-1.5 \%$, although the shape of the graphite is beneficially changed to fine sphere-like instead of being normal flake-like, as shown in Table 2. In contrary, because much an amount of $\mathrm{V}$ is dissolved in the matrix, there are little $\mathrm{V}$ carbides solidified in the roll- $\mathrm{B},-\mathrm{C}_{1},-\mathrm{C}_{2},-\mathrm{C}_{3}$ and $-\mathrm{D}$ during casting, though these rolls contain $0.55 \% \mathrm{~V}$.

However, $\mathrm{Nb}$ has a greater affinity with carbon in the matrix than $\mathrm{V}$, so it is more likely to be crystallized as $\mathrm{NbC}$ carbides, when subjected to the solidification process. As a result, there is a little $\mathrm{Nb}$ content remained in the matrix, ${ }^{11)}$ so the volume percentage and the shape of the graphite formed during solidification can not be influenced by $\mathrm{Nb}$ contents.

If the amount of the sphere-like graphite is low, fire crack resistance will decrease sharply. In order to increase the volume percentage of the graphite, it is necessary to change $\mathrm{Si}$ content from $0.9 \%$ to $1.3 \%$ and $\mathrm{Cr}$ content from $1.8 \%$ to $1.6 \%$, under the constant $\mathrm{V}$ and $\mathrm{Nb}$ contents. As a result, the amount of the graphite was increased to about $2.7 \%$, but the shape of the graphite was turned to be fine flake-like (Fig. $1(\mathrm{f})$ ).

Overall hardness values of the rolls can be classified to three groups, the first is the higher hardness values which appeared at the roll- $\mathrm{C} 1,-\mathrm{C}_{2}$ and $-\mathrm{C}_{3}$. The second group is the roll-B and -D. The third group is the lowest hardness that was shown in the roll-A. This trend is identical to the volume percent of the total carbides. It seems to be quite possible that, bulk hardness is the comprehensive results of the hardness of the matrix, kind and volume fraction of the carbides, because all of the rolls keep the same matrix as martensite, hardness values of the rolls must follow the trend of volume percentage of the total carbides, as shown in Table 2.

Although we specifically described the influence of $\mathrm{V}$, $\mathrm{Nb}, \mathrm{Si}$ and $\mathrm{Cr}$ on the CRIC rolls above, some phenomena shown in the microstructural examination are still difficult to interpret. For instance, why the examining location moves toward inner region of the section, the volume fraction of the rod-like $\mathrm{NbC}$ carbides increases, whereas that of the square-like $\mathrm{NbC}$ carbides decreases oppositely. So, it

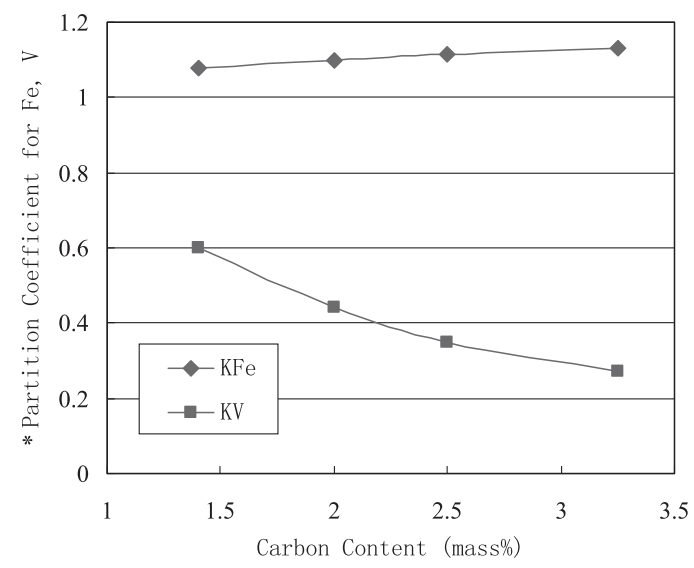

* Partition Coefficient: it means the ratio of alloy contents at the core of dendrite to the average contents of alloy. It was determined with EPMA.

Fig. 7. Effect of the carbon content on partition coefficient for $\mathrm{Fe}$ and $\mathrm{V} .{ }^{10)}$ 
requires further inspection to explain the effects of the variety of factors on the microstructure in order to manufacture the CRIC rolls with more improved performances.

\section{Conclusions}

In this paper, the effects of $\mathrm{V}, \mathrm{Nb}, \mathrm{Si}$ and $\mathrm{Cr}$ elements on microstructure of six CRIC rolls manufactured by a small vertical centrifugal casting method were investigated.

(1) V influences the amount and shape of the graphite. The volume percentage of graphite is sharply reduced by adding V. In addition, the shape of the graphite is changed to beneficially fine sphere-like instead of being normal flake-like at the CRIC rolls.

(2) $\mathrm{Nb}$ has great affinity with carbon to form the high hardness $\mathrm{NbC}$ carbides. The number of the $\mathrm{NbC}$ carbides is increased by increasing the $\mathrm{Nb}$ contents, but if $\mathrm{Nb}$ contents exceed eutectic line PQ, there will be a density-induced $\mathrm{NbC}$ segregation zone which appears at the outer region of the section.

(3) The amount of the graphite increases with increasing $\mathrm{Si}$ and reducing $\mathrm{Cr}$ contents, but the shape of the graphite is turned to be finely flake-like instead of being sphere-like.

(4) The volume percentage of the rod-like $\mathrm{NbC}$ carbides increases when the location moves toward inner region of the thickness. Simultaneously, that of the cubic-like NbC carbides decreases.
(5) The roll- $\mathrm{C}_{2}$ appeared to be reasonable in terms of correlation between microstructure and rolling performance, but it needs to increase the spherical graphite by 3-5\% through suitable adjustment of microstructural factors.

\section{Acknowledgements}

The authors thank a lot HANY, from Egypt for the careful revision of the manuscript, and manager Ai-jongcheng, Liuna and Zhong-xianquen of the research division of the roll manufacture works in the machinery manufacture Co. in Anshan iron and steel group, for their helpful discussion on the microstructural analysis of the rolls.

\section{REFERENCES}

1) W. L. Bradley and M. N. Srinivasan: Int. Mater. Rev., 35 (1990), 129.

2) G. Byun, S. Oh, C. G. Lee and S. Lee: Metall. Mater. Trans. A, 30A (1999), 234.

3) K. Ogi: Imono, 66 (1994), 764

4) L. A. Dobrzanski: Steel Res., 57 (1986), 37.

5) G. L. F. Powell and P. G. Lloyd: Metallography, 14 (1981), 271

6) T. Nylen: Proc. of Roll 2000+, Advances in Mill Roll Technology Conf., IOM Communications Ltd., UK, (1999), 121.

7) W. Min-jia and W. Yan: Trans. of Mater. Heat Treat., 26 (2004), 74.

8) K. Euh, Y. C. Kim, K. Shin, S. Lee and N. J. Kim: Mater. Sci. Eng. A., 346 (2003), 228.

9) K. C. Hwang, S. Lee and H. C. Lee: Mater.Sci.Eng. A., 254 (1998), 296.

10) K. Ogi and H. Miyahara: What's New in Roll Technologies of the World?, ISIJ, Tokyo, (1995), 1.

11) G. Hoyle: High Speed Steels, Butterwoth \& Co. Ltd, Cambridge, UK, (1988), 80. 